\section{KAJIAN IDENTIFIKASI KOTA AMAN (SAFECITY) DI KOTA SEMARANG}

\author{
Eko Setiawan ${ }^{*}$, Holi Bina Wijaya \\ Departemen Perencanaan Wilayah dan Kota, Fakultas Teknik, \\ Universitas Diponegoro
}

\author{
Jurnal Pengembangan Kota (2018) \\ Volume 6 No. 1 (1-8) \\ Tersedia online di: \\ http://ejournal2.undip.ac.id/index.php/jpk \\ DOI: 10.14710/jpk.6.1.1-8
}

\begin{abstract}
Abstrak. Keamanan (safety) menjadi isu yang penting khususnya dalam suatu kota. Aspek keamanan tersebut terkait dengan meningkatnya tindakan kriminalitas di suatu kota sehingga mengganggu aktivitas dan mobilitas masyarakat yang ada di dalamnya. Oleh karena itu, penelitian ini bertujuan untuk mengidentifikasi penerapan konsep Kota Aman (safecity) sehingga dapat meningkatkan keamanan kota, terutama di Kota Semarang sebagai kasus dalam penelitian ini. Metode yang digunakan adalah konsep three onion layers yang melihat faktor-faktor yang dapat memengaruhi dan mengakibatkan keamanan terganggu. Penelitian ini menemukan bahwa Semarang sebagai kota dengan kepadatan penduduk tinggi, sektor perdagangan dan jasa memiliki aktivitas tinggi, perlu meningkatkan respon kota terutama terkait dengan penindakan kejahatan dan kekerasan di Semarang.
\end{abstract}

Kata kunci: kota aman; kejahatan; city responses

[Title: Study of Safecity Identification in Semarang]. Safety is an important issue especially in a city. Safety includes the response toward increased criminal acts in a city that disrupts the activities and mobility of the people in it. Safety becomes an important aspect so it is necessary to do an assessment on how safe is Semarang and how to increase the safety of Semarang? This research applied the concept of three onion layers that examine the factors that can affect and lead to safety disruptions. This research found that Semarang with high population density, high trade and service activities, has to improve the response on safety issue particularly related to the crime and violence in Semarang.

Keyword: safecity; criminal; city responses

Cara mengutip: Setiawan, E. \& Wijaya, H. B. (2018). Kajian Identifikasi Kota Aman (Safecity) di Kota Semarang. Jurnal Pengembangan Kota. Vol 6 (1): 1-8. DOI: 10.14710/jpk.6.1.1-8

\section{PENDAHULUAN}

Keamanan kota dapat diketahui dengan melihat faktor-faktor yang mempengaruhinya (South African Cities Network, 2016). Konsep three onion layers melihat faktor-faktor tersebut diantaranya faktor risiko struktural/sosial dan kondisi dari kejahatan dan kekerasan. Kedua faktor tersebut kemudian akan diketahui faktor mana yang perlu diprioritaskan dengan menghasilkan respon kota terhadap faktor. Respon ini dapat dituangkan dalam perencanaan dan perancangan kota atau kawasan dengan mempertimbangkan keamanan masyarakat sebagai elemen utama (Cozens, Saville, \& Hillier, 2005; Kamalipour, Faizi, \& Memarian, 2014).

Amerika Serikat, setelah peristiwa serangan tehadap gedung WTC pada 9 September 2001 menjadikan isu keamanan mendapat tempat utama tidak hanya untuk keamanan kota tetapi juga untuk keamanan nasional. Indonesia sendiri mengalami peristiwa serangan terorisme, yang terkini di kawasan Sarinah Jakarta pada 14 Januari 2016. Kejadian tersebut menunjukan bahwa ancaman keamanan terhadap tindakan kriminalitas dapat merugikan dan merusak. Ancaman tersebut dapat berdampak buruk pada pertumbuhan dan perkembangan suatu kota. Selain itu, ancaman

ISSN 2337-7062 (Print), 2503-0361 (Online) (C 2018

This is an open access article under the CC-BY-NC-ND license (http://creativecommons.org/licenses/by-nc-sa/4.0/). - lihat halaman depan @ 2018

*Email: eko_1211@yahoo.co.id

Diterima 11 Desember 2017, disetujui 2 Februari 2018 
tersebut juga dapat berpengaruh terhadap warga yang tinggal di dalamnya. Aspek keamanan menjadi elemen yang tak terpisahkan dalam suatu kota.

Jawa Tengah memiliki tingkat risiko terkena kejahatan (crime rate) paling rendah yaitu 48 kasus akan tetapi berdasarkan total jumlah kejahatan (crime total) Jawa Tengah masuk dalam 10 besar dengan jumlah kejahatan yang dilaporkan yaitu 15.958 kasus (BPS Kota Semarang, 2016). Hal ini menunjukkan bahwa Jawa Tengah masih cukup tinggi tingkat kriminalitasnya. Semarang sebagai ibu kota dari Jawa Tengah pada tahun 2016 terdapat tindak pidana sebanyak 12.574 dengan kata lain Kota Semarang memiliki jumlah tertinggi dari ke-35 kota dan kabupaten yang ada di Jawa Tengah yaitu $33,84 \%$ dari jumlah total kejahatan yang dilaporkan. Berdasarkan data tersebut, Kota Semarang diharapakan dapat meningkatkan keamanan, dikarenakan Kota Semarang merupakan kota yang memiliki tingkat aktivitas yang tinggi. Hal tersebut dapat berdampak pada pertumbuhan dan perkembangan Kota.

Dengan kondisi tersebut, maka perlu dilakukan penelitian untuk mengkaji kota aman untuk mengetahui faktor-faktor dari tindakan kriminalitas yang dapat mempengaruhi keamanan suatu kawasan atau kota sehingga dapat meningkatkan keamanan Kota Semarang. Penelitian ini diharapkan menghasilkan gambaran yang berbeda dengan yang dilakukan pada penelitian pada kotakota di Afrika (South African Cities Network, 2016) dengan pertimbangan bahwa Kota Semarang memiliki karakteristik penduduk dan isu-isu sosial yang berbeda dengan kota-kota di Afrika.

\section{METODE PENELITIAN}

Tulisan ini berdasarkan pada hasil penelitian yang menggunakan pendekatan kuantitatif deskriptif. Melihat indikator kejahatan dan kekerasan faktor risiko/struktural yang kemudian dikaitkan dengan keamanan suatu kota dari konsep kota aman. Berikut konsep three layers onion (Gambar 1) yang kemudian menjadi acuan dalam membentuk variabel dan indikator penelitian (Tabel 1 ).

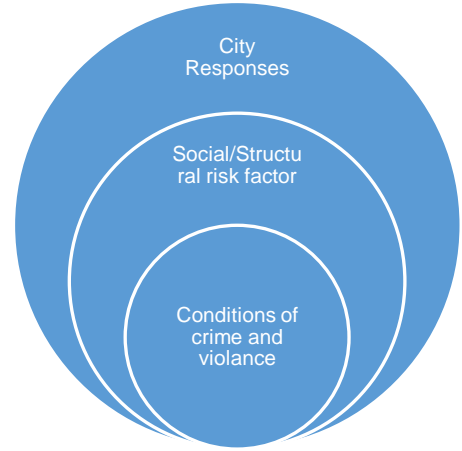

Gambar 1. Three Layers "Onion". (South African Cities Network, 2016, p. 31)

Tabel 1. Variabel dan Indikator Penelitian

\begin{tabular}{ccc}
\hline No. & Variabel & Indikator \\
\hline & Kondisi Kejahatan dan Kekerasan \\
& Obyektif & Tingkat pembunuhan \\
& \multicolumn{3}{c}{ Risiko } & Tingkat pencurian \\
& \multicolumn{2}{c}{ Struktural/sosial } \\
2 & Urbanisasi & Kepadatan Penduduk \\
& Marjinalisasi & Tingkat Kemiskinan \\
& & Respon Kota \\
3 & Kota aman & Jumlah penduduk \\
& & Tata guna lahan \\
\hline
\end{tabular}

Konsep safecity dapat diartikan sebagai suatu upaya pencegahan terhadap tindakan yang dapat mengancam keamanan serta keselamatan masyarakat yang tinggal di dalam suatu wilayah dalam hal ini adalah kriminalitas (Susilorini \& MI, 2007; UN-Habitat, 2007). Upaya tersebut didapatkan dengan mellihat faktor-faktor apa saja yang dapat memicu terjadinya kriminalitas sehingga dapat mengancam keamanan dan keselamatan. Dengan melihat hal tersebut akan didapat upaya pencegahanya. Kota aman memiliki komponen diantaranya (Anuar, Bookhari, \& Aziz, 2012; Rozhana, dkk., 2015)

\section{- Night-time Activities}

Aktivitas malam yang terjadi pada suatu kota dapat menjadi potensi terjadinya tindak kejahatan (Kyttä, Kuoppa, Hirvonen, Ahmadi, \& Tzoulas, 2014). Aktivitas pada malam hari dapat menciptakan tempat-tempat yang memilki potensi seseorang untuk bersosialisasi, berkeliaran pada malam hari serta cenderung meningkatkan pengkonsusmi minuman beralkohol khususnya pada bar, klub dan diskotik. 


\section{- Travelling and Public Transportation}

Merupakan risiko yang terjadi pada transportasi publik. Komponen ini melihat keamanan lingkungan yang ada pada kawasan tersebut (Yavuz \& Welch, 2010).

\section{HASIL DAN PEMBAHASAN}

\subsection{Analisis Sumber Daya Manusia (SDM) Kota Semarang}

\section{- $\quad$ Tingkat kepadatan Penduduk}

Kota Semarang memiliki luas wilayah $37.380 \mathrm{Ha}$, yang memiliki 16 Kecamatan. Kecamatan dengan tingkat kepadatan tertinggi berada di Kecamatan Semarang Selatan $13.431 \mathrm{Km} / \mathrm{Jiwa}$ dengan persentase sebesar $11,56 \%$ sedangkan kepadatan penduduk paling rendah yang ada di Kota Semarang adalah Kecamatan Tugu sebesar 1.009 Km/jiwa dengan persentase 0,8\% (Gambar 2). Berdasarkan konsep risiko sosial/struktural menunjukan kepadatan penduduk di Kota Semarang 31,25\% masuk dalam kategori kepadatan tinggi dan $43,75 \%$ kategori kepadatan sedang. Hal ini perlu penanganan dalam mengurangi kepadatan penduduk yang ada di Semarang dikarenakan dapat menyebabkan meningkatnya tindak kejahatan.

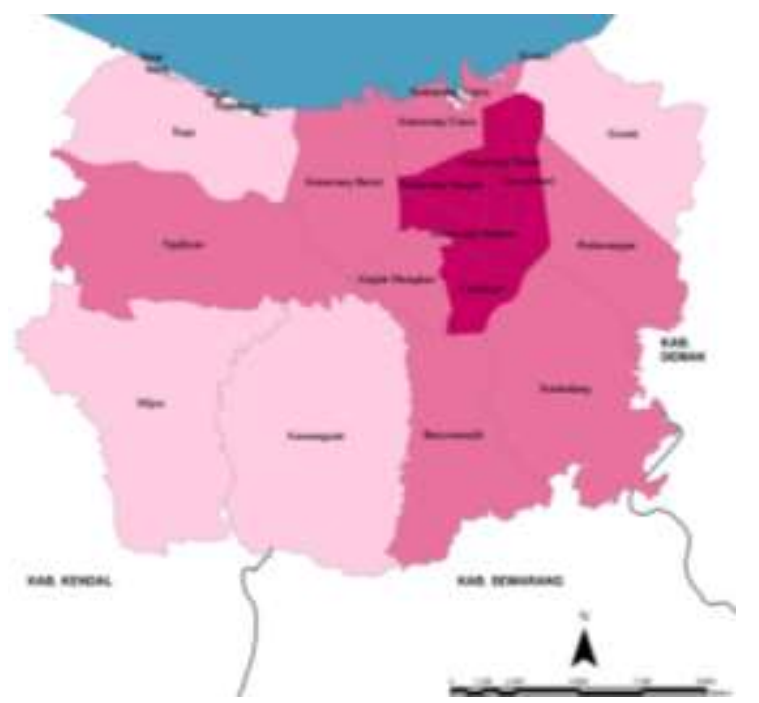

Gambar 2. Tingkat Kepadatan Penduduk Semarang 2017

\section{- Tingkat Kemiskinan Kota Semarang}

Kecamatan dengan angka kemiskinan tinggi ada pada kecamatan Semarang Utara dengan persetase $34,83 \%$, sedangkan dengan angka kemiskinan rendah terdapat pada Kecamatan Banyumanik dengan persentase 10,89\% (Gambar 3). Persentase kemiskinan tersebut didapat dari perhitungan jumlah penduduk kecamatan dengan angka kemiskinan per kecamatan. Berdasarkan konsep kota aman pada bagian risiko sosial/struktural, menunjukan bahwa penanganan pengurangan kemiskinan dengan prioritas pertama ada pada lima kecamatan yaitu Kecamatan Semarang Utara, Kecamatan Tugu, Kecamatan Candisari, Kecamatan Semarang Selatan, dan Kecamatan Gayamsari (lihat Gambar 3). Kelima kecamatan tersebut menjadi prioritas utama dalam pengurangan kemiskinan dikarenakan hal tersebut dapat menjadi faktor terjadinya suatu kejahatan.

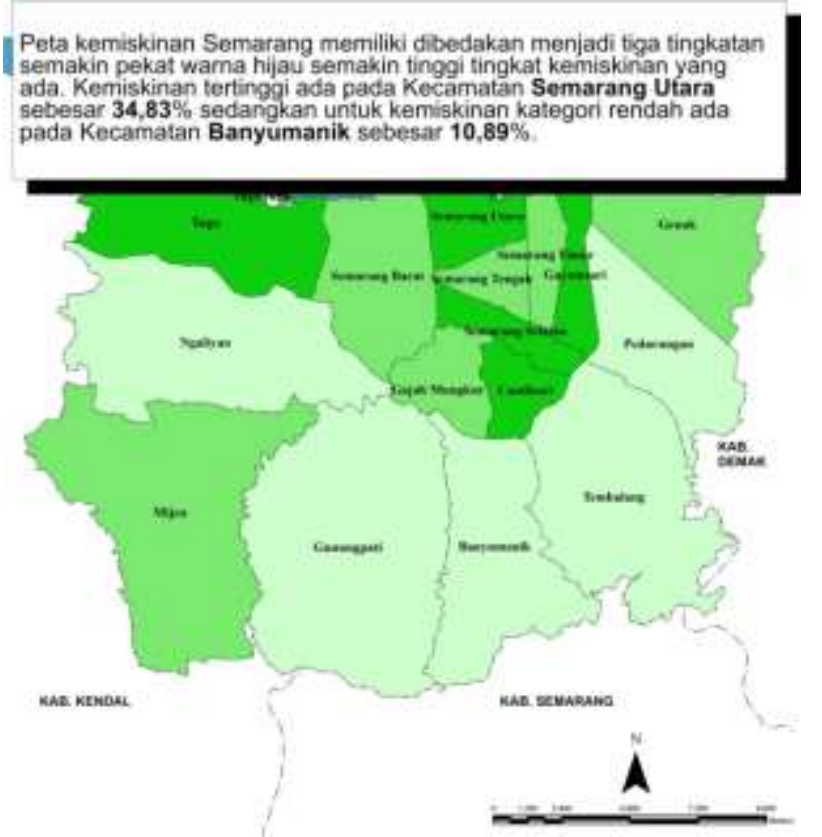

Gambar 3. Tingkat Kemiskinan Kota Semarang 2017

\section{- Analisis Kesenjangan Pendapatan}

Kurva pada Gambar 4 menunjukan bahwa koefisien tertinggi ada pada tahun 2013 sebesar 0,35 yang menunjukan bahwa kesenjangan pendapatan yang ada di Kota Semarang bertaraf sedang. Dan nilai koefisien terendah ada pada tahun 2014 dengan nilai 0,31 yang menunjukan kesenjangan pendapatan ada pada taraf rendah. 


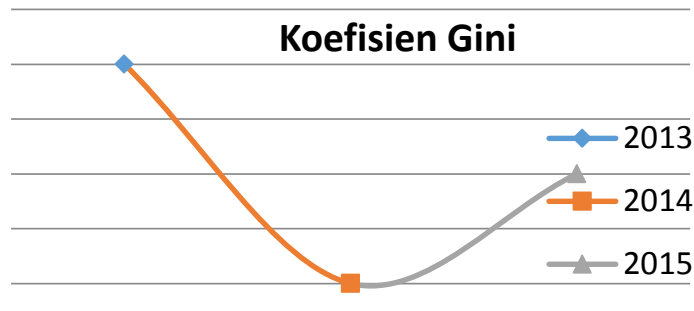

Gambar 4. Kurva Koefisien Gini Kota Semarang

\subsection{Tingkat Kejahatan di Kota Semarang}

\section{- Tingkat Pembunuhan}

Data pembunuhan di bawah Kecamatan yang memiliki kasus pembunuhan tertinggi terhitung dari tahun 2013 sampai dengan 2016 ada pada Kecamatan Gayamsari sebanyak 3 kasus pembunuhan (lihat Gambar 5).

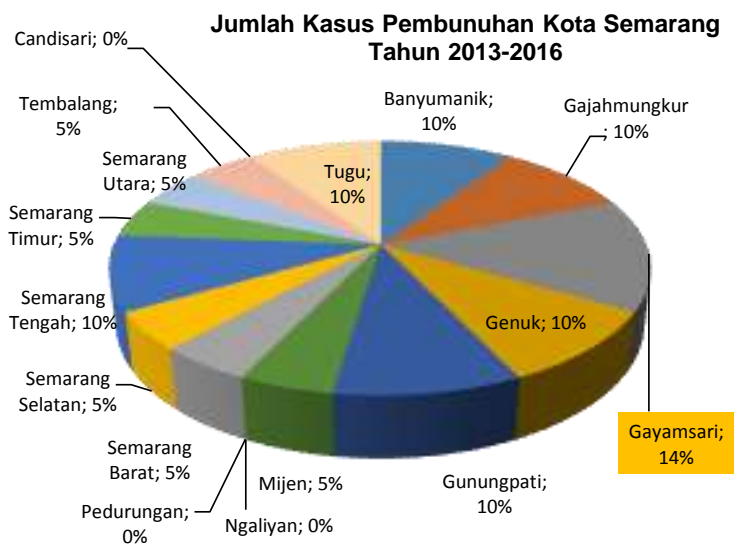

Gambar 5. Jumlah Kasus Pembunuhan Kota Semarang

\section{- $\quad$ Tingkat pencurian}

Data pencurian di bawah menunjukkan kecamatan dengan tingkat pencurian tertinggi adalah Kecamatan Gayamsari yaitu sebanyak 16 kasus (Gambar 6).

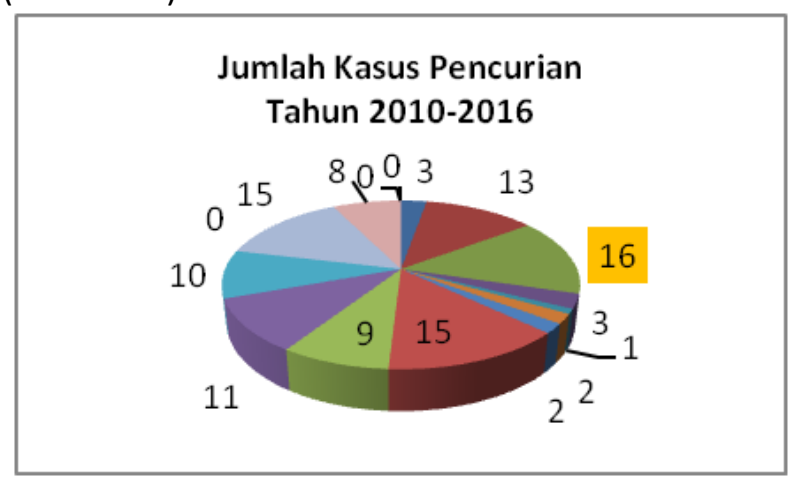

Gambar 6. Jumlah Kasus Pencurian Kota Semarang

\section{- Rekapitulasi Kejahatan Kota Semarang}

Dari data yang diperoleh terdapat 21 kasus dan pencurian memiliki 108 kasus. Dari jumlah kejahatan yang ada pada data diketahui bahwa Kecamatan Gayamsari memiliki jumlah kasus kejahatan yaitu mencapai 19 kasus, sedangkan untuk jumlah kasus terendah ada pada Kecamatan Candisari tidak ada kasus kejahatan di Kecamatan tersebut.

Sebaran jumlah kejahatan di Kota Semarang dapat dilihat pada Gambar 7. Gambar 7 menunjukan warna semakin merah merupakan daerah dengan jumlah kasus terbanyak dan warnah hijau mengindikasikan jumlah kasus paling sedikit. Berdasarkan konsep kota aman pada analisis kondisi kejahatan dan kekerasan menunjukan 50\% wilayah di Kota Semarang masuk dalam kawasan rawan kejahatan khususnya pada kasus pembunuhan dan Pencurian. Kondisi tersebut dapat berdampak pada perkembangan Kota Semarang.

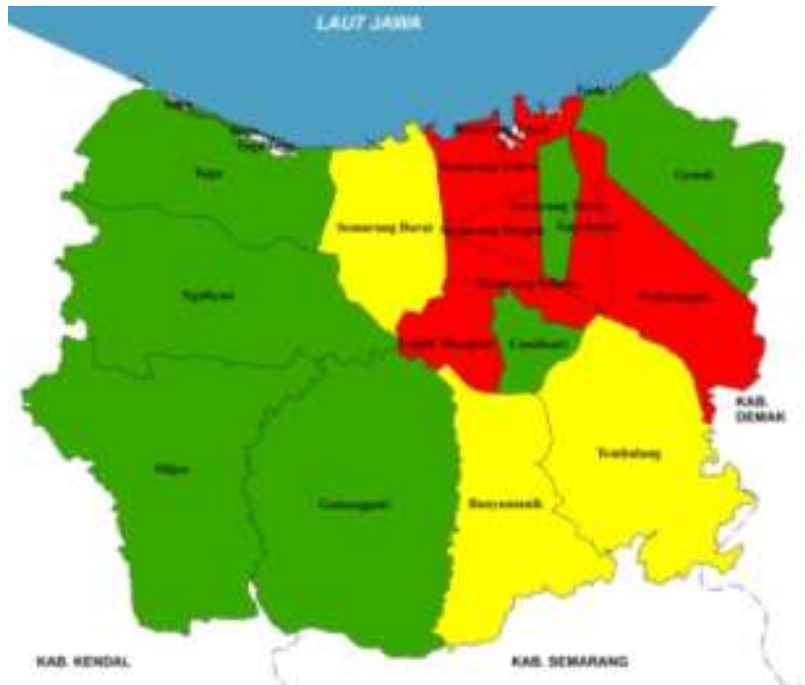

Gambar 7. Peta Jumlah Kejahatan Kota Semarang

\section{- Analisis Korelasi Jumlah Kejahatan dengan Jumlah Kemiskinan}

Setelah melakukan proses analisis korelasi, berikut tabel ouput analisis korelasi antara jumlah kejahatan dengan jumlah kemiskinan (lihat Tabel 3). 
Tabel 3. Output Analisis Korelasi

\begin{tabular}{cccc} 
& & Pencurian & Pembunuhan \\
\hline \multirow{2}{*}{$\begin{array}{c}\text { Jumlah } \\
\text { penduduk } \\
\text { miskin }\end{array}$} & \begin{tabular}{c} 
P. \\
\cline { 2 - 4 }
\end{tabular} & .428 & $-.502^{\prime \prime}$ \\
\cline { 2 - 4 } & $\begin{array}{c}\text { Sig. } \\
\text { (2-tailed) }\end{array}$ & .098 & .047 \\
\hline
\end{tabular}

Berdasarkan Tabel 3, jumlah penduduk miskin dengan kasus pencurian tidak ada korelasi dengan nilai $0,428>0,05$. Sedangkan jumlah penduduk miskin dengan kasus penbunuhan memiliki korelasi yang cukup kuat dengan namun berlawanan arah dengan nilai Sig. 0,047<0,05 dan nilai korelasi memiliki tanda negatif (-).

\subsection{Identifikasi Wilayah Night-time Activities dan Travelling and Public}

Hasil overlay antara kepadatan penduduk kota Semarang tertinggi dengan tata guna lahan Kota Semarang menunjukkan bahwa wilayah dengan aktivitas tinggi pada siang maupun jam malam ada pada Kecamatan Candisari, Kecamatan Semarang Selatan, Kecamatan Semarang Tengah yang ditunjukan dengan warna yang semakin pekat serta bulatan yang besar (Gambar 8). Ketiga Kecamatan tersebut perlu perhatian dalam keamanan pada jam malam dikarenakan memiliki potensi tindak kejahatan.

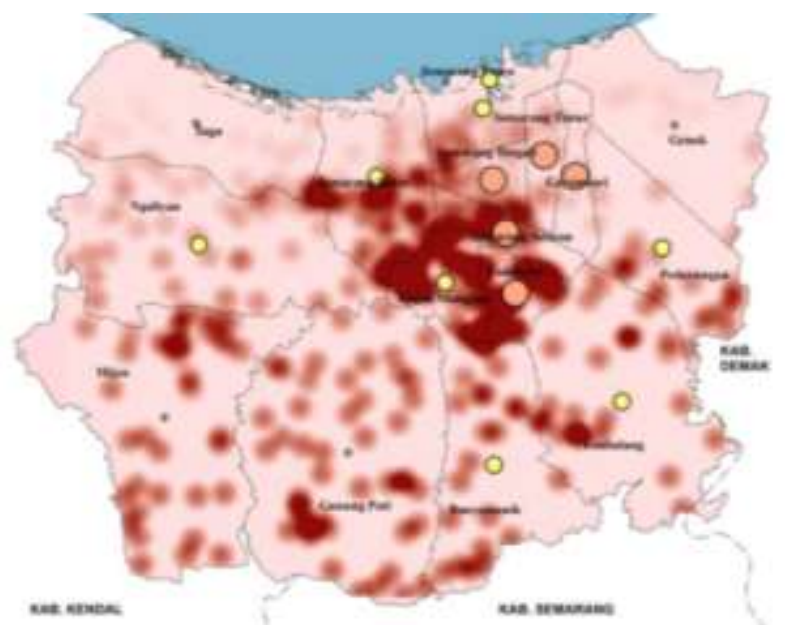

Gambar 8. Overlay Kepadatan Penduduk dengan Tata Guna Lahan Kota Semarang

\subsection{Analisis City Responses}

Kecamatan Semarang Utara, Kecamatan Gayamsari, Kecamatan Semarang Selatan memiliki tingkat kemiskinan tinggi dan tingkat kejahatan sangat rawan, ditunjukkan dengan warna hijau yang pekat serta memiliki bulatan merah (Gambar 9). Ketiga Kecamatan tersebut perlu dilakukan perbaikan mengenai city responses baik dari sektor pemerintah maupun sektor kepolisian. Kemudian pada Kecamatan Pedurungan terlihat bahwa memiliki tingkat kemiskinan rendah, namun pada tingkat kejahatan sangat rawan hal tersebut menunjukan perlu perbaikan city responses pada sektor kepolisian guna mengurangi tingkat kejahatan di Kecamatan tersebut. Selain itu, pada Kecamatan Candisari terlihat bahwa tingkat kemiskinan tinggi dan tingkat kejahatan tergolong aman, hal ini menunjukan perlu perbaikan city responses pada sektor pemerintah untuk mengurangi tingkat kemiskinan.

Pada sisi lain, terdapat kecamatan dengan tingkat kemiskinan rendah dan tingkat keamanan tergolong aman di antaranya Kecamatan Tugu, Kecamatan Gunung Pati, Kecamatan Ngaliyan, dan Kecamatan Genuk. Kondisi tersebut menunjukan keempat kecamatan tersebut memiliki city responses yang baik dari sektor pemerintah maupun kepolisian hal ini perlu dipertahankan guna meningkatkan perkembangan dan pertumbuhan suatu kawasan.

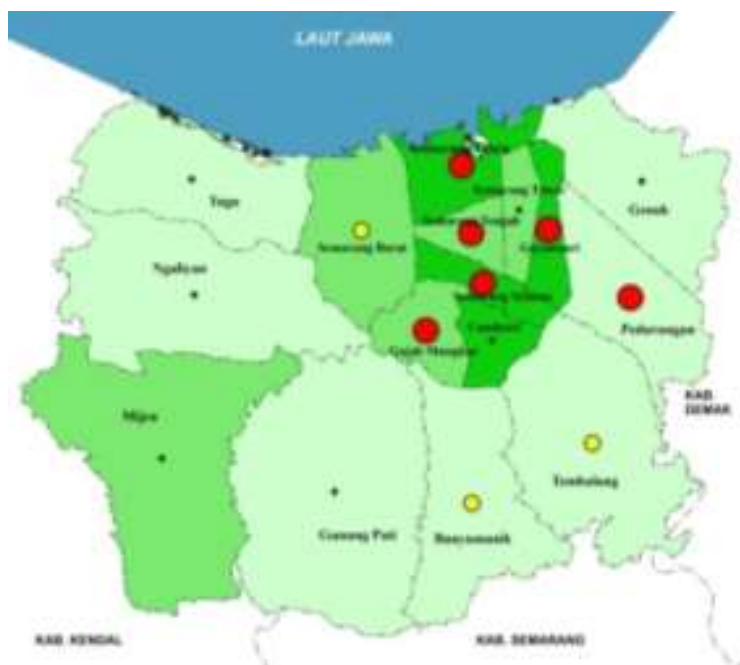

Gambar 9. Analisis City Responses 


\subsection{Pencegahan Kejahatan dari Kepolisian}

Kepolisian berusaha melakukan inovasi dalam hal pengurangan tingkat kejahatan hal tersebut terbukti dari diluncurkannya sebuah aplikasi berbasis android yang bernama Smile Police. Smile Police merupakan bagian dari website Kepolisian Daerah Jawa tengah yang dirancang untuk mengintegrasikan seluruh sistem informasi dan aplikasi yang digunakan oleh Kepolisian Daerah Jawa Tengah ke dalam web-based interface sesuai dengan kebutuhan Kepolisian Daerah Jawa Tengah (Wahyuni \& Maesaroh, 2018). Selain itu, aplikasi tersebut merupakan program sistem informasi yang bekerja berdasarkan GPS (Global Positioning System). Smile Police memiliki fitur utama yaitu Panic Button yang mana tombol tersebut apabila di tekan akan langsung terhubung menuju server, kemudian dari server akan memberitahu anggota dari kepolisian yang terdekat dari lokasi panggilan. Apabila panggilan tersebut palsu selama tiga kali maka dari server akan memblock nomor telepon yang teregistrasi pada user tersebut sehingga nomor tersebut tidak dapat menggunakan aplikasi Smile Police kembali.

Smile Police baru diluncurkan sekitar lima bulan. Namun kehadiran aplikasi tersebut kurang diketahui oleh masyarakat dikarenakan sosialisasi yang kurang khususnya di Kota Semarang. Selain itu, SDM dari anggota kepolisian yang kurang mengakibatkan masih sedikit yang terdaftar dalam anggota kepolisian smile police.

\subsection{Analisis Penerapan Kota Aman}

Dari analisis yang telah dilakukan, tingkat keamanan Kota Semarang sebagai berikut:

- Perlu pendekatan yang tepat guna mengurangi tingkat kejahatan pada tingkat Kota. Berdasarkan data dari Polrestabes Semarang (2017), jumlah data menunjukan bahwa kejahatan tertinggi ada pada pencurian sebanyak 3.328 kasus hal tersebut menunjukan perlu penanganan dan strategi khusus dalam mengurangi angka kejahatan pada jenis pencurian (lihat Gambar 10). Sehingga yang menjadi perhatian adalah kasus pencurian guna mengurangi tingkat kejahatan yang ada di Kota Semarang.

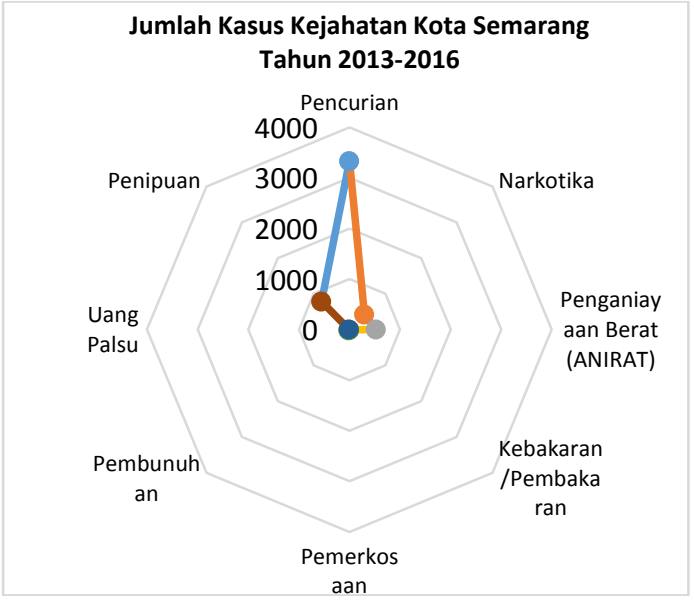

Gambar 10. Jumlah Kejahatan Kota Semarang

- Tingkat kemiskinan di Kota semarang cenderung pada kawasan pusat Kota Semarang dan kawasan pesisir pantai seperti Kecamatan Semarang Utara, Kecamatan Tugu, Kecamatan Gayamsari, dan Kecamatan Candisari.

- Dalam fokus pada keamanan, tingkat keamanan yang paling rawan adalah pada kawasan perdagangan dan jasa serta masuk dalam kawasan dengan angka kemiskinan tinggi.

- Berdasarkan jumlah kasus pembunuhan yang ada di Kota Semarang, Kecamatan Candisari merupakan kecamatan dengan kasus pembunuhan tertinggi. Melihat dari analisis night-time activities dan traveling and Public transportation, Kecamatan Gayamsari masuk dalam wilayah yang memiliki tingkat kepadatan tinggi namun tingkat aktivitas cukup rendah.

- Dari jumlah kasus pembunuhan di Kota Semarang, Kecamatan Gayamsari merupakan Kecamatan dengan kasus pembunuhan tertinggi. Melihat dari analisis night-time activities dan traveling and public transportation, Kecamatan Gayamsari masuk dalam wilayah yang memiliki tingkat kepadatan tinggi namun tingkat aktivitas cukup rendah.

- Berdasarkan jumlah kasus pembunuhan di Kota Semarang, Kecamatan Candisari merupakan Kecamatan dengan kasus pembunuhan tertinggi. Melihat dari analisis night-time activities serta traveling and public transportation, Kecamatan Gayamsari masuk wilayah yang memiliki tingkat aktivitas tinggi. 
- Data menunjukan Kecamatan Gayamsari memiliki kasus pecurian tertinggi.

Secara keseluruhan, berikut pemetaan jumlah pembunuhan (Gambar 11) dan jumlah kasus pencurian (Gambar 12) di Kota Semarang.

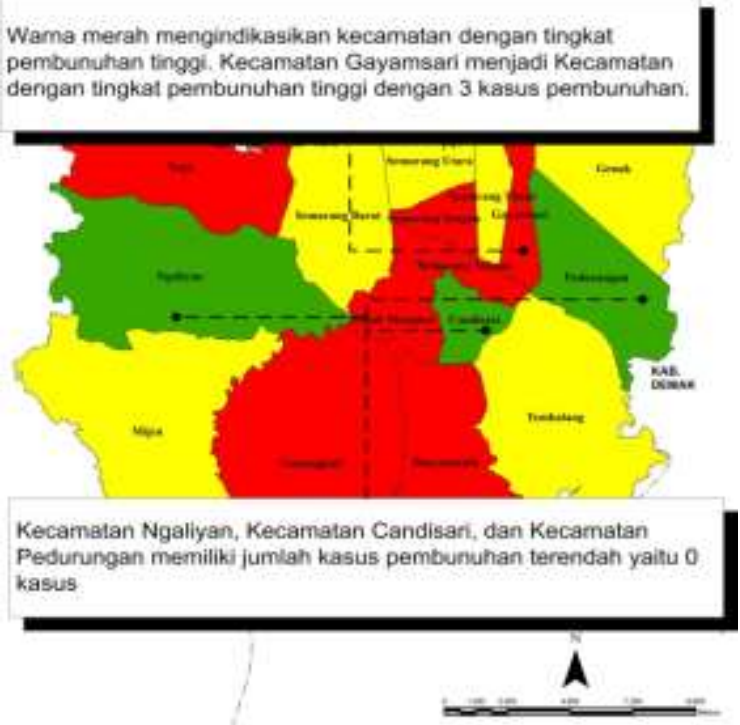

Gambar 11. Jumlah Kasus Pembunuhan Semarang

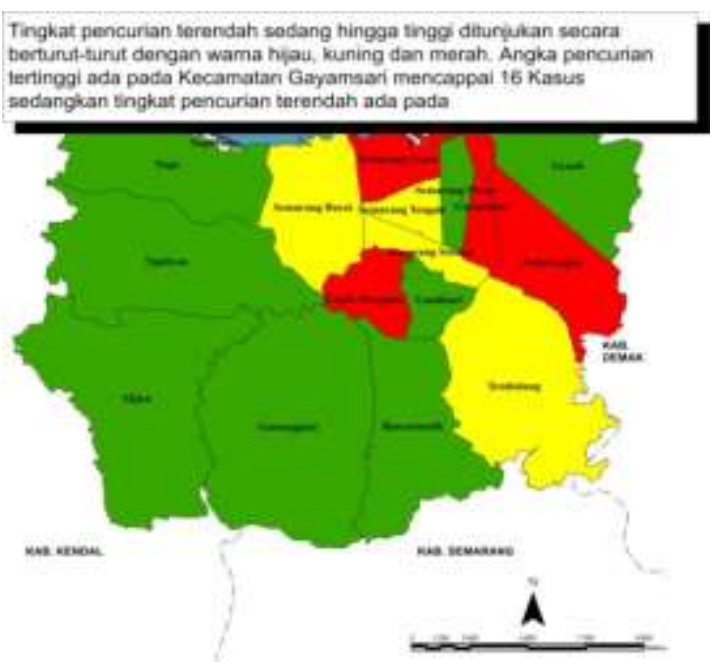

Gambar 12. Jumlah Kasus Pencurian

Penerapan kota aman di Kota semarang perlu memperhatikan aspek tingkat kemiskinan, kepadatan penduduk serta kondisi tata guna lahan yang ada di Kota Semarang. Berdasarkan analisis yang telah dilakukan, perlu perbaikan mengenai city responses. Perbaikan city responses terbagi menjadi dua sektor yaitu sektor pemerintah dan sektor kepolisian difokuskan pada lima kecamatan diantaranya Kecamatan Pedurungan, Kecamatan Gayamsari, Kecamatan Semarang Selatan,
Kecamatan Candisari, dan Kecamatan Semarang Utara. Kelima kecamatan tersebut perlu peningkatan city responses dengan melakukan perbaikan SDM dan peningkatan sektor keamanan dari kepolisian, diharapakan dapat menurunkan tingkat kerawanan mengenai kejahatan di Semarang.

\section{KESIMPULAN}

Identifikasi kota aman ditinjau dari kondisi kejahatan dan kekerasan menunjukkan bahwa Kota Semarang tergolong cukup rawan kejahatan yang ditunjukkan dengan kasus tertinggi ada pada pencurian. Kemudian melihat dari korelasi jumlah penduduk miskin denga jumlah kasus pencurian dan pembunuhan, hanya kasus pembunuhan yang memiliki hubungan yang kuat namun berlawanan arah.

Sedangkan, jika ditinjau dari risiko sosial/struktural Kota semarang memiliki rata-rata kesenjangan pendapatan yang tergolong rendah (Susanti, 1994) kemudian dari kondisi tingkat kepadatan aktivitas pusat kota menjadi aktivitas tertinggi. Hal tersebut menunjukan tingkat aktivitas tertinggi memiliki risiko terjadinya tindak kejahatan.

Kota Semarang yang tergolong rawan dalam kejahatan, apabila dikaitkan dengan konsep smart city yang sedang dicanangkan Pemerintah Kota Semarang perlu penanggulangan dalam hal menangani kejahatan karena konsep smart city memiliki salah satu pilar utama yaitu keamanan di kota terkait people (manusia) dan environment (lingkungan). Selain itu, konsep smart city juga berkaitan dengan cara sensor yang dapat menghasilkan aliran data baru secara real time dengan geo-positioning yang tepat (Batty, 2013). Hal tersebut sejalan dengan konsep safecity, Sehingga hal ini perlu menjadi perhatian dalam meningkatkan keamanan kota di Semarang.

Peningkatan keamanan dengan melihat identifikasi kota aman ditinjau dari respon kota, perlu perbaikan mengenai respon suatu kota di Semarang baik itu sektor pemerintah maupun sektor kepolisian. Menurut Kunarto (1996), perbaikan yang dapat dilakukan pada sektor pemerintah adalah strategi tidak langsung yang memfokuskan 
pada masyarakat. Sedangkan kepolisian menggunakan strategi langsung fokus pada kejahatan yang ada.

\section{DAFTAR PUSTAKA}

Anuar, A. N. A., Bookhari, S. N., \& Aziz, N. A. (2012). The Effectiveness of Safe City Programme as Safety Basic in Tourism Industry: Case Study in Putrajaya. Procedia - Social and Behavioral Sciences, 42, 477-485. doi:https://doi.org/10.1016/j.sbspro.2012. 04.213

Batty, M. (2013). Big Data, Smart Cities and City Planning. Dialogues in Human Geography, 3(3),

274-279. doi:https://doi.org/10.1177/20438206135 13390

BPS Kota Semarang. (2016). Kota Semarang dalam Angka 2016. Semarang: BPS Kota Semarang.

Cozens, P. M., Saville, G., \& Hillier, D. (2005). Crime Prevention Through Environmental Design (CPTED): A Review and Modern Bibliography. Property Management, 23(5), 328-356. doi:10.1108/02637470510631483

Kamalipour, H., Faizi, M., \& Memarian, G. (2014). Safe Place by Design: Urban Crime in Relation to Spatiality and Sociality. Current Urban Studies, 2(2), 152-162. doi:10.4236/cus.2014.22015

Kunarto. (1996). Tren Kejahatan dan Peradilan Pidana. Jakarta: Cipta Manunggal.

Kyttä, M., Kuoppa, J., Hirvonen, J., Ahmadi, E., \& Tzoulas, T. (2014). Perceived Safety of the Retrofit Neighborhood: A Location-Based Approach. URBAN DESIGN International, 19(4), 311-328. doi:https://doi.org/10.1057/udi.2013.31

Polrestabes Semarang. (2017). Rekapitulasi Kejahatan Tahun 2014-2016. Semarang: Polrestabes Semarang.

Rozhana, A., Yunos, M., Mydinb, M. A. O., Isaa, N. K. M., Ariffina, N. F. M., \& Atiah, N. (2015).
Building the Safe City Planning Concept: An Analysis of Preceding Studies. Jurnal Teknologi, 75(9), 95-100. doi:https://doi.org/10.11113/jt.v75.5241

South African Cities Network. (2016). State of Urban Safety in South Africa Report 2016. A Report of the Urban Safety Reference Group. Diakses dari http://www.sacities.net/wpcontent/uploads/2016/PDF/SACN-UrbanSafety-2016-Report.pdf.pdf, 12 Oktober 2017

Susanti, H. (1994). Indikator-indikator Makroekonomi: Lembaga Penerbit, Fakultas Ekonomi, Universitas Indonesia bekerja sama dengan Lembaga Penyelidikan Ekonomi dan Masyarakat, Fakultas Ekonomi, Universitas Indonesia.

Susilorini, R., \& MI, R. (2007). Fractured Based Approach for Structural Element DesignSafe Building, Safe City. Paper presented at the Proceeding Third International Conference on Economic and Urban Management "City Marketing, Heritage, and Identity), PMLP Unika Soegijapranata, Semarang.

UN-Habitat. (2007). Global Report on Human Settlements: Enhancing Urban Safety and Security. Diakses dari https://www.un.org/ruleoflaw/files/urban safetyandsecurity.pdf, 23 Oktober 2017

Wahyuni, N., \& Maesaroh, M. (2018). Analisis Inovasi Pelayanan di Kepolisian Daerah Jawa Tengah (Studi Kasus Smile Police). Journal of Public Policy and Management Review, 7(2). Retrieved from https://ejournal3.undip.ac.id/index.php/jp pmr/article/view/19944/18843

Yavuz, N., \& Welch, E. W. (2010). Addressing Fear of Crime in Public Space: Gender Differences in Reaction to Safety Measures in Train Transit. Urban Studies, 47(12), 2491-2515. doi:https://doi.org/10.1177/00420980093 59033 